\title{
Detection of pine woodwasp in Pinus taeda in São Paulo State, Brazil
}

\author{
Carlos Frederico Wilcken ${ }^{1}$ Amanda Rodrigues de Souza ${ }^{\text {* }}$ \\ Barbara de Oliveira Puretz ${ }^{1}$ Gabriella Ferreira de Camargo ${ }^{1}$
}

${ }^{1}$ Laboratório de Controle Biológico de Pragas Florestais, Faculdade de Ciências Agronômicas, Universidade Estadual Paulista "Júlio de Mesquita Filho" (UNESP), 18610-307, Botucatu, SP, Brasil. E-mail: agroamandarodrigues@yahoo.com.br. "Corresponding author.

\begin{abstract}
The woodwasp Sirex noctilio (Fabricius) (Hymenoptera: Siricidae) is one of the main pests of Pinus plantations in South America. The aim of this study is to report the occurrence of S. noctilio in Pinus taeda in Botucatu, São Paulo, Brazil. The surveys were carried out in the arboretum of Faculdade de Ciências Agronômicas (FCA) da Universidade Estadual Paulista "Júlio de Mesquita Filho" (UNESP), campus Botucatu, SP where six species of Pinus are distributed in blocks of 100 trees. Resin beads were observed on the trunks and stems of Pinus species. In post-flight evaluation it was reported that $8.77 \%$ of P. taeda trees showed symptoms of oviposition by S. noctilio. A female S. noctilio was found performing oviposition. Sirex noctilio is present in Botucatu, increasing the geographical distribution of the pest in São Paulo State.
\end{abstract}

Key words: Sirex noctilio, exotic pest, forest pest, occurrence, pine.

Detecção da vespa-da-madeira em Pinus taeda no estado de São Paulo, Brasil

RESUMO: A vespa-da-madeira, Sirex noctilio (Fabricius) (Hymenoptera: Siricidae) é uma das principais pragas de plantações de Pinus na América do Sul. O objetivo deste estudo foi relatar a ocorrência de Sirex noctilio (Hymenoptera: Siricidae) em Pinus taeda em Botucatu, São Paulo, Brasil. As pesquisas foram realizadas no arboreto da Faculdade de Ciências Agronômicas (FCA) da Universidade Estadual Paulista “Júlio de Mesquita Filho" (UNESP), campus Botucatu, SP, composto por seis espécies de Pinus distribuídas em blocos de 100 árvores. Respingos de resina foram visualizados nos troncos das espécies de Pinus. Na avaliação pós-revoada verificou-se que 8,77\% das árvores de P. taeda apresentaram sintomas de oviposição por $S$. noctilio. Uma fêmea de S. noctilio foi encontrada realizando oviposição. Sirex noctilio está presente em Botucatu, ampliando a distribuição geográfica da praga no estado de São Paulo.

Palavras-chave: Sirex noctilio, praga exótica, praga florestal, ocorrência, pinheiro.

An important pine pest is the pine woodwasp, Sirex noctilio Fabricius, 1793 (Hymenoptera: Siricidae). This pest is native to Europe, Asia, and North Africa, and it has become a strong threat in the Southern hemisphere countries where it was introduced (IEDE et al., 2015). In South America, detections were recorded in Uruguay (1980), Argentina (1985), Brazil (1988), and Chile (2001), with records of high levels of pest population (ECHEVERRIA, 1986; MADERNI, 1998; CISTERNAS, 2007). In Brazil, the first record of $S$. noctilio was reported in Canela, Gramado, and São Francisco de Paula, in Rio Grande do Sul State in 1988 (IEDE et al.,
1988). This pest was reported in states of Santa Catarina, in 1989 (MENDES et al., 1993), Paraná, in 1994 (IEDE et al., 1998), and in São Paulo, in 2004, and most recently in Minas Gerais, in 2005 (IEDE \& ZANETTI, 2007) (Figure 1). Sirex noctilio was reported in four municipalities as Itapeva, Itapirapuã Paulista, Capão Bonito, and Jundiaí, in the state of São Paulo (IEDE; ZANETTI, 2007).

A female lays up to 226 eggs per female and the incubation period ranges from 14 to 28 days, and adult longevity varies between four to five days in Brazil (CARVALHO et al., 1993). After hatching, larvae begin feeding and they bore galleries close to the laying sites. The formation of pupae occurs inside 


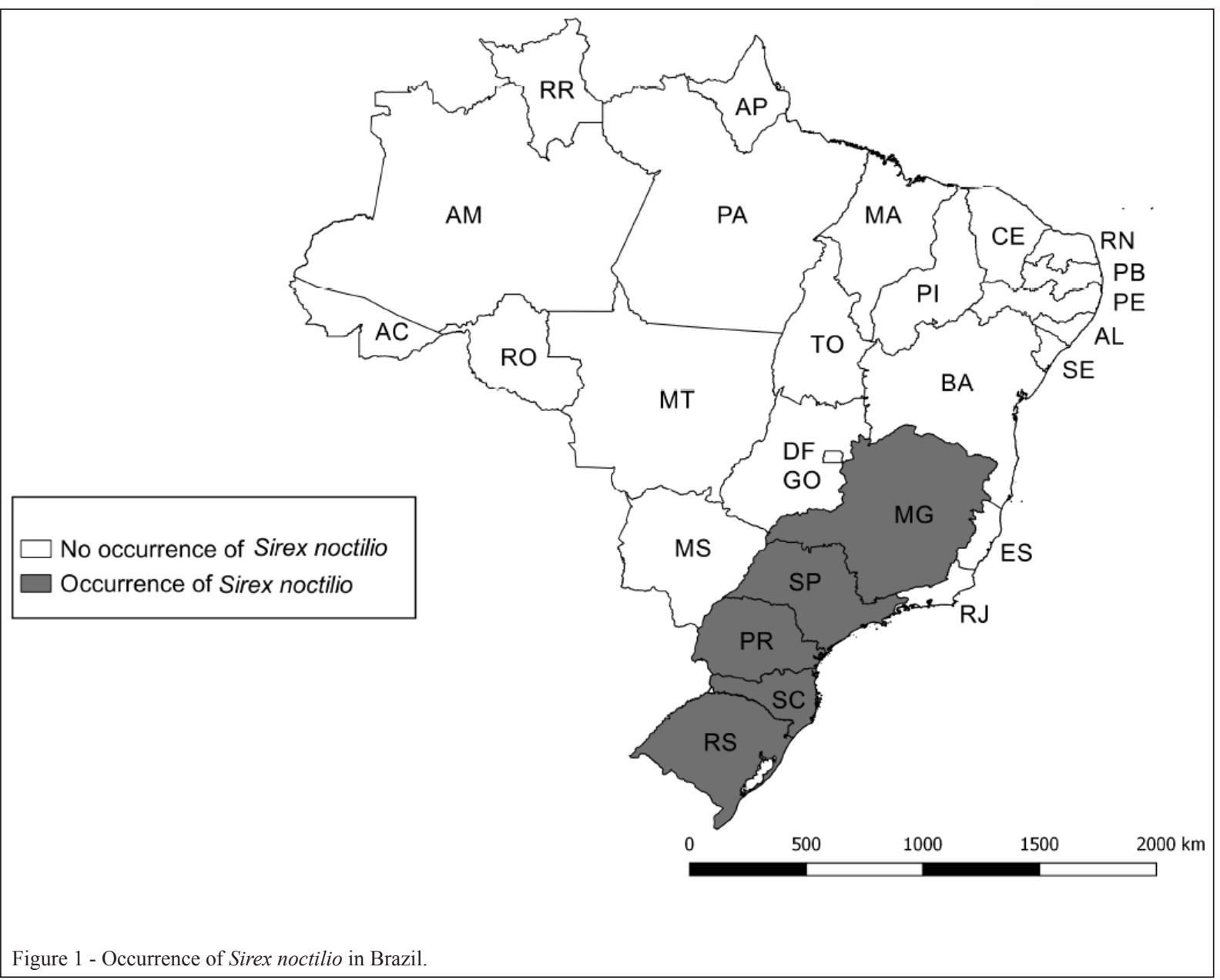

the trunk (IEDE et al., 2015). In general, the pine woodwasp prefers dominated trees, as these trees are stressed and smaller, with a thinner trunk diameter (IEDE et al., 2015), between $7 \mathrm{~cm}$ and $26 \mathrm{~cm}$ at breast height (DBH) (NEUMANN et al., 1987), more than eight years old, and these are under stress (IEDE et al., 2015). The adoption of appropriate silvicultural practices to maintain the health and vigor of Pinus plantations is the main principle to prevent severe attacks (IEDE et al., 1998).

The main damage caused by $S$. noctilio is boring the wood caused by larvae; tree death occurs due to combined action of phytotoxic mucus and pathogenic fungus Amylostereum areolatum (Chaillet ex Fr) Boidin (Russulales: Amylostereaceae) growth (IEDE et al., 1998; NAHRUNG et al., 2016). The most visible external signs are canopy chlorosis, drought, and fall of pine needles, resin beads, and adult emergence holes. These factors affected the wood quality, limiting its use in the market (IEDE et al., 1998). The monitoring of areas infested by $S$. noctilio is performed by identification of trees with symptoms of external attack by adults, mainly resin beads along the trunk (PENTEADO, 2008). The main management strategy for the pine woodwasp is biological control using nematode Deladenus (= Beddingia) siricidicola Bedding, 1968 (Nematoda: Neothylenchidae), the egg parasitoid Ibalia leucospoides Hochenwarth, 1785 (Hymenoptera: Ibaliidae), and the ectoparasitoids of mature larvae, Megarhyssa nortoni Cresson, 1864 and Rhyssa persuasoria Linnaeus, 1758 (Hymenoptera: Ichneumonidae) (HURLEY et al., 2007; CAMERON, 2012).

Signs of S.noctilio were reported in an experimental area of Pinus in Botucatu, state of São Paulo, Brazil during the periodic monitoring of leafcutting ants in this area (Figure 2). Thus, the aim of 


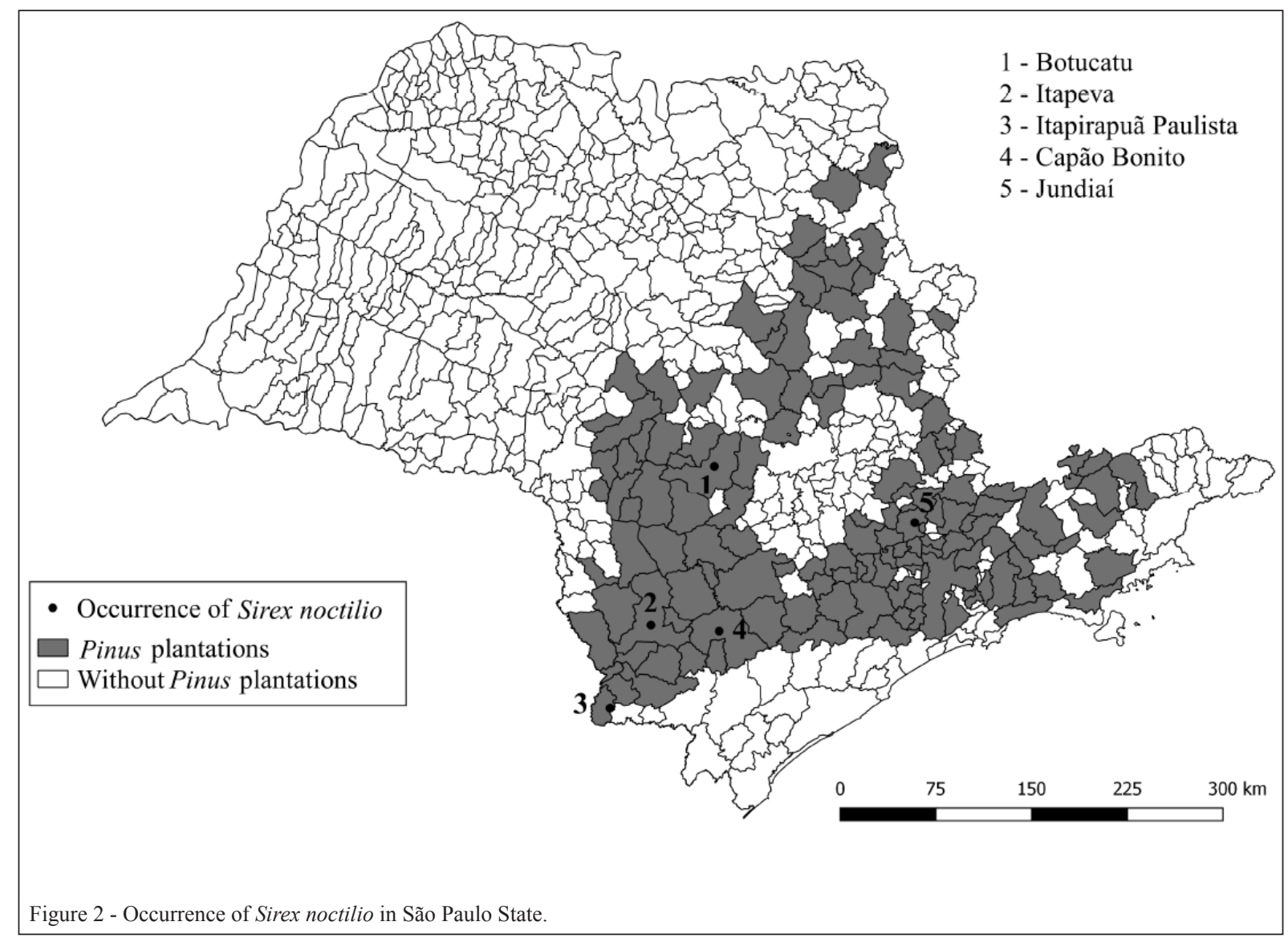

this study was to report a new area of occurrence of $S$. noctilio in São Paulo.

A female of $S$. noctilio was found ovipositing in the trunk of a P. taeda tree (Figure 3), and resin beads were observed in the tree during a control operation of cutting ants in the arboretum of Faculdade de Ciências Agronômicas, Universidade Estadual Paulista "Júlio de Mesquita Filho" (FCA/ UNESP) - Campus of Botucatu. This female was collected, fixed, and incorporated in the collection of the Entomological Museum of the Department of Plant Protection in FCA/UNESP.

Later, evaluations to find $S$. noctilio were carried out in other pine species of the arboretum. The Pinus species evaluated were: $P$. caribaea caribaea, P. caribaea hondurensis, P. caribaea bahamensis, P. oocarpa, and P. elliottii, planted between 1992 and 1999, in blocks of 100 trees (Table 1). Pinus taeda was the only species in the arboretum which was attacked by $S$. noctilio. Pre-infested trees were evaluated looking for symptoms of canopy chlorosis and dried pine needles, but no symptoms were observed, confirming no fungus colonization in trees. Measurements of the diameter at breast height (DBH) were performed on all species of Pinus (Table 1). The average DBH of $P$. taeda was $20.9 \mathrm{~cm}$ (Table 1), confirming the preference of the pine woodwasp to oviposite in trees between $8 \mathrm{~cm}$ to $26 \mathrm{~cm}$ in diameter (NEUMANN, 1987). A total of 57 Pinus trees present in the arboretum, $8.77 \%$ (five trees) showed symptoms of $S$. noctilio oviposition. The other pine species in the arboretum have larger diameters compared to the P. taeda block (Table 1).

The dispersion of $S$. noctilio in Botucatu may have been through timber transport, due to the presence of the pest, Pinus spp., in the vicinity of the arboretum. The detection of one female $S$. noctilio in this municipality occurred in October. In Brazil, the occurrence of pine woodwasp adult pest vary from October to January (CARVALHO et al., 1993).

The detection of a $S$. noctilio female was recorded in Botucatu, SP, during the estimated period 


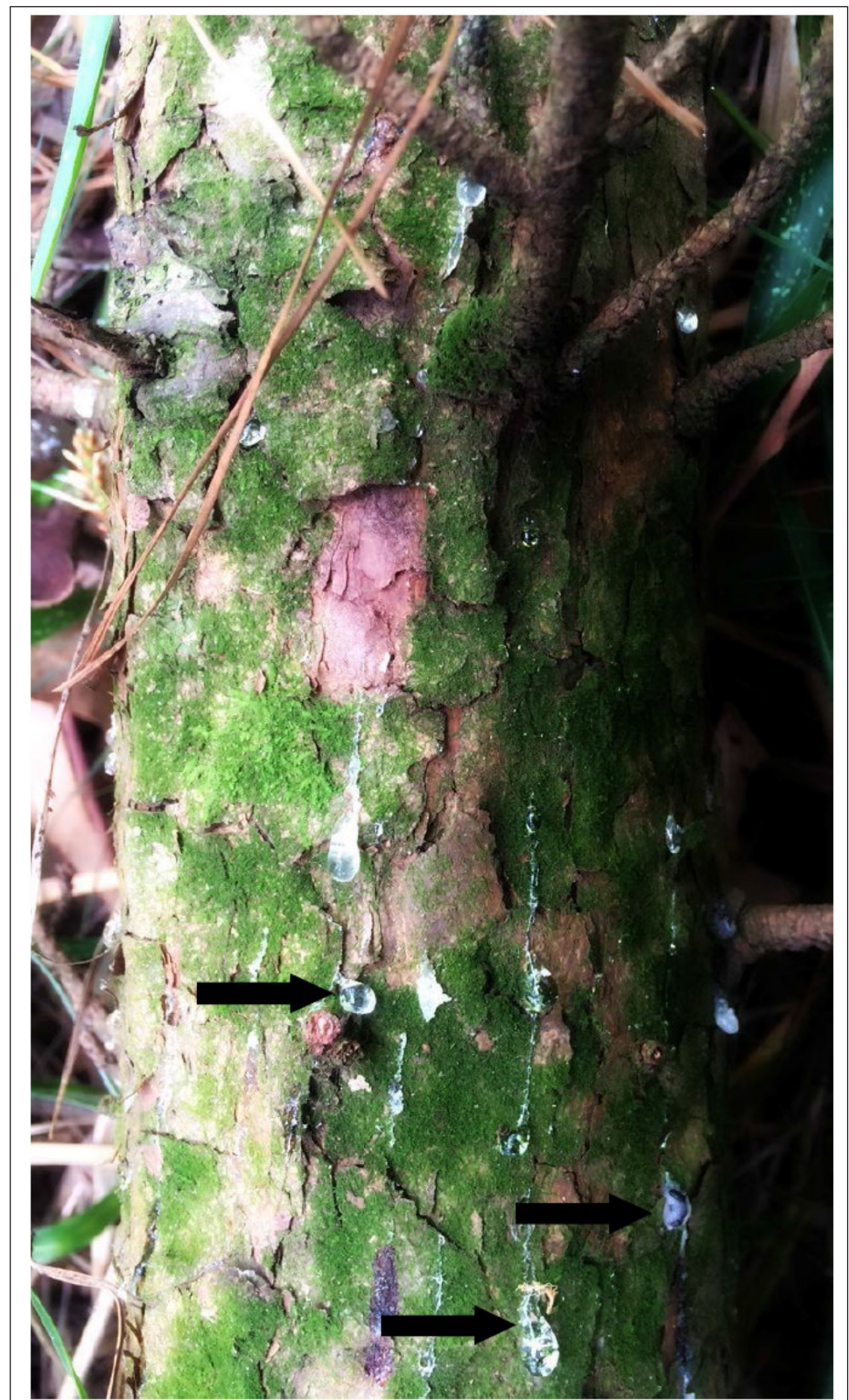

Figure 3 - Resin beads in Pinus taeda caused by S. noctilio in Botucatu, SP, Brazil, October, 2016. 
Table 1 - Diameter at breast height (DBH) of Pinus spp. in Botucatu, SP, Brazil (2016).

\begin{tabular}{|c|c|c|c|c|}
\hline \multirow[t]{2}{*}{ Species } & \multicolumn{4}{|c|}{ - Trees with DBH>7cm--1 } \\
\hline & Number of trees & Rate DBH (cm) & Number of trees & Rate DBH $(\mathrm{cm})$ \\
\hline P. taeda & 57 & 20.9 & 5 & 19.48 \\
\hline P. caribaea var. caribaea & 32 & 26.1 & - & - \\
\hline P. caribaea var. hondurensis & 52 & 29.6 & - & - \\
\hline P. caribaea var. bahamensis & 15 & 35.7 & - & - \\
\hline P. elliotti & 30 & 23.4 & - & - \\
\hline P. oocarpa & 27 & 35.7 & - & - \\
\hline
\end{tabular}

of occurrence of this pest in Brazil. Evolution of the typical symptoms of a $S$. noctilio attack, such as, drying and death of $P$. taeda trees in this municipality was not observed. The surveys carried out on pine species of the arboretum will continue in the following years, considering that the establishment of this pest was not confirmed in Botucatu yet.

In this context, population surveys on $S$. noctilio, in areas with Pinus plantations, in municipalities of the central region of São Paulo (Figure 2) has become necessary, to confirm the possible establishment of this pest and to guide management procedures based on biological control, using natural enemies. In this region there are Pinus plantations for wood and resin production, and the presence of the $S$. noctilio will cause economic losses for the farmers and forest companies.

\section{ACKNOWLEDGEMENTS}

To Conselho Nacional de Desenvolvimento Científico e Tecnológico (CNPq) (Process: 142131/2012-1), Coordenação de Aperfeiçoamento de Pessoal de Nível Superior (CAPES) and Programa Cooperativo sobre Proteção Florestal (PROTEF) of the Instituto de Pesquisas e Estudos Florestais (IPEF) for financial support.

\section{REFERENCES}

CISTERNAS, M.B. Official program for detection and control of Sirex noctilio (Hymenoptera: Siricidae) in Chile. In: INTERNATIONAL Sirex SYMPOSIUM AND WORKSHOP, 2007, Pretoria \& Pietermaritzburg, South Africa. Anais... Pretoria, South Africa, 2007. 64 p. p.21.

CAMERON, E.A. Parasitoids in the management of Sirex noctilio: looking back and looking ahead. In: SLIPPERS, B.; GROOT, P.; WINGFIELD, M.J. The Sirex woodwasp and its fungal symbiont: Research and management of a worldwide invasive pest. Nova York: Springer, 2012. Cap.8, p.103-117.

CARVALHO, A.G. et al. Bioecologia de Sirex noctilio F. 1793 (Hymenoptera: Siricidae) em povoamentos de Pinus taeda L.
In: Conferência regional da vespa-da-madeira, Sirex noctilio, na América do Sul, 1992, Florianópolis, SC. Anais... Colombo: Embrapa/FAO/USA/FUNCEMA, 1993. V.1. 278p. p.85-96.

ECHEVERRIA, N.E. Avispa barrenadora de los pinos Sirex noctilio (Hymenoptera: Siricidae). Buenos Aires: IFONA Report C.F.C., 1986. 23p. (Bulletin, 2).

HURLEY, B.P. et al. A comparison of control results for the alien invasive woodwasp, Sirex noctilio, in the southern hemisphere. Agricultural and Forest Entomology, v.9, p.159-171, 2007. Available from: <http://www.fabinet.up.ac.za/publication/ pdfs/113-2007 hurley slippers wingfield agric for ent.pdf>. Accessed: Jan. 05,2017 . doi: 10.1111/j.1461-9563.2007.00340.x.

IEDE, E.T. et al. Vespa-da-madeira, Sirex noctilio Fabricius. In: VILELA, E.F.; ZUCCHI, R.A. Pragas Introduzidas no Brasil: Insetos e ácaros. Piracicaba: Fealq, 2015. Cap.48, p. 810-826.

IEDE, E.T. et al. Programa nacional de controle a vespa-da-madeira no Brasil. In: IEDE, E.T. et al. Proceedings of a conference: Training in the control of Sirex noctilio by the use of natural enemies. Morgantown: USDA Forest Service, 1998. p.43-51.

IEDE, E.T.; ZANETTI, R. Ocorrência e recomendações para o manejo de Sirex noctilio Fabricius (Hymenoptera, Siricidae) em plantios de Pinus patula (Pinaceae) em Minas Gerais, Brasil. Revista Brasileira de Entomologia, v.5, p. 529-531, 2007. Available from: <http://dx.doi.org/10.1590/S008556262007000400023>. Accessed: Jan. 05, 2017. doi: 10.1590/ S0085-56262007000400023.

IEDE, E.T. et al. Primeiro registro de ataque de Sirex noctilio em Pinus taeda no Brasil. Colombo: EMBRAPA-CNPF, 1988. 12p. (Bulletin, 20).

MADERNI, J.F.P. Sirex noctilio F. present status in Uruguay. In: IEDE, E.T. et al. Proceedings of a conference: Training in the control of Sirex noctilio by the use of natural enemies. Morgantown: USDA Forest Service, 1998. p. 81-82.

MENDES, C.J. et al. Monitoramento da vespa-da-madeira no estado de Santa Catarina. In: Conferência regional da vespa-damadeira, Sirex noctilio, na América do Sul, 1992, Florianópolis, SC. Anais... Colombo: Embrapa/FAO/USA/FUNCEMA, 1993. V.1. 278 p. p. $183-190$.

NAHRUNG, H.F. et al. Performance of Sirex noctilio's biocontrol agent Deladenus siricidicola, in known and predicted hosts.

Ciência Rural, v.48, n.2, 2018. 
Biological Control, v. 103, p. 54-61, 2016. Available from: $<$ http:// dx.doi.org/10.1016/j.biocontrol.2016.08.003>. Accessed: Jan. 04, 2017. doi: 10.1016/j.biocontrol.2016.08.003.

NEUMANN, F.G. et al. The Sirex wasp in Victoria. Melbourne: Lands and Forests Division, Department of Conservation, Forests and Lands, 1987. 41p. (Bulletin, 29).
PENTEADO, S.R.C. et al. Utilização da amostragem sequencial para avaliar a eficiência do parasitismo de Deladenus (Beddingia) siricidicola (Nematoda: Neotylenchidae) em adultos de Sirex noctilio (Hymenoptera: Siricidae). Ciência Florestal, v.18, p.223-231, 2008. Available from: <http://dx.doi. org/10.5902/19805098459>. Accessed: Jan. 03, 2017. doi: $10.5902 / 19805098459$. 